TOMASZ WIELEBSKI

MATEUSZ J. TUTAK

\title{
Diecezjalne Rady Duszpasterskie w Polsce. Między ideałem a rzeczywistością
}

Obecnie Kościół w Polsce realizuje trzyletni (2010-2013) program duszpasterski Kościót domem i szkoła komunii. Hasłem przewodnim tego programu jest myśl zaczerpnięta z listu apostolskiego Novo millennio ineunte bł. Jana Pawła II: Czynić Kościót domem i szkoła komunii (NMI 43). Papież napisał w nim, że to wielkie zadanie, jakie czeka nas w rozpoczynajacym się tysiacleciu, jeżeli chcemy pozostać wierni Bożemu zamysłowi, a jednocześnie odpowiedzieć na najgłębsze oczekiwanie świata (tamże).

W realizowanym programie duszpasterskim postawiono trzy cele ogólne, które wyznaczają kierunek pracy $\mathrm{w}$ kolejnych latach. Celem pierwszego roku pracy („W komunii z Bogiem” - 2010/2011) było odkrywanie i pogtębianie duchowości komunii. Kolejny rok pracy („Kościół naszym domem”- 2011/2012) ma służyć odnawianiu i wzmacnianiu struktur komunijnych Kościoła. Ostatni rok działań duszpasterskich („Być solą ziemi” - 2012/2013) ma być poświęcony krzewieniu duchowości komunii ${ }^{1}$. Trzeba zwrócić uwagę na logikę realizowanego programu, wyrażającą się w bardzo ścisłej łączności poszczególnych lat pracy. Chodzi najpierw o odkrywanie istoty komunii (jedności człowieka z Bogiem),

Tomasz W I E L E B S K I, ks. dr, kierownik Sekcji Teologii Pastoralnej Wydziału Teologicznego UKSW w Warszawie oraz wykładowca Wyższego Seminarium Duchownego Diecezji Warszawsko-Praskiej, Warszawa, e-mail: tomwielebski@gmail.com

Mateusz J. T U T A K, mgr lic., asystent w Sekcji Teologii Pastoralnej Wydziału Teologicznego UKSW w Warszawie, Warszawa, e-mail: matitux@gmail.com

${ }^{1}$ K. K a n to w s ki, Sz. S t u 1 k o w s k i: W Komunii z Bogiem. W: Komisja Duszpasterstwa KEP: W Komunii z Bogiem. Kościół domem i szkoła komunii. Program duszpasterski dla Kościoła w Polsce na lata 2010-2013. Rok 2010/2011. Red. Sz. S t u ł k o w s k i. Poznań 2010 s. 16. 
aby na tym doświadczeniu wiary budować i umacniać struktury komunijne, które później staną się narzędziem ewangelizacji. Realizacji programu mają towarzyszyć pierwsze Krajowe Kongresy Diecezjalnych (IX 2012) i Parafialnych (IX 2013) Rad Duszpasterskich ${ }^{2}$.

Drugi rok realizowanego programu duszpasterskiego był poświęcony tworzeniu i ożywianiu działalności różnorodnych struktur komunijnych w diecezjach i parafiach jako narzędzi służących uczeniu wszystkich członków Kościoła odpowiedzialności za Jego kształt ${ }^{3}$. To one mają pomagać w tworzeniu Kościoła jako communio, pobudzając pasterzy $i$ wiernych do uważnego stuchania siebie nawzajem (NMI 45). Jednym z takich narzędzi jest Diecezjalna Rada Duszpasterska (dalej DRD), która ma, pod przewodnictwem biskupa diecezjalnego, $b a$ dać (...) wszystko, co dotyczy działalności pasterskiej, a także rozważać i przedstawiać praktyczne wnioski (KPK kan. 511). W tej perspektywie warto dokonać diagnozy działalności DRD i zaproponować kierunkowe działania na przyszłość. Diagnoza będzie dotyczyć poszukiwania odpowiedzi na to, czy i w jaki sposób DRD, kierując się wskazaniami Magisterium, realizują swoje zadania. Przyszłościowe wskazania mają dotyczyć tego, co trzeba czynić, aby bardziej aktywizować i wykorzystywać potencjał duchownych i świeckich członków DRD do działań na rzecz Kościoła diecezjalnego. Trzeba też zastanawiać się nad tym, w jaki sposób owoce spotkań DRD mają być przekładane na konkretne działania.

Szukając odpowiedzi na postawione pytania, pracownicy Sekcji Teologii Pastoralnej Wydział Teologiczny UKSW postanowili przeprowadzić badania socjologiczne dotyczące funkcjonowania działalności DRD. Tego typu działanie jest konkretną realizacją nauczania II Soboru Watykańskiego, który wskazując na konieczność właściwego harmonizowania kultury ludzkiej i obywatelskiej z nauką chrześcijańską, podkreślił konieczność uznawania i stosowania w duszpasterstwie nie tylko zasad teologii, ale także nauk świeckich, zwłaszcza psychologii i socjologii (zob. KDK 62). Prowadzone badania i płynące z nich wnioski stanowią jeden $\mathrm{z}$ wykorzystywanych przez teologię pastoralną paradygmatów działań, zwany paradygmatem trzech etapów. Ujmuje się go w formie sylogizmu praktycznego, w którym przesłanką większą jest zasada objawiona odkryta w wyników poszukiwań nauk teologicznych, przesłankę mniejszą stanowią dane zaczerpnięte z badań socjologicznych, psychologicznych, pedagogicznych i innych, a wniosek, będący zasadą urzeczywistniana się Kościoła, ma charakter teologiczny. Najpierw ukazuje się jakiś wycinek działalności pastoralnej Kościoła w

\footnotetext{
${ }^{2}$ Tamże.

${ }^{3}$ Por. S. G ą d e c k i: Stowo wstępne. W: Komisja Duszpasterstwa KEP. Kościót naszym domem. Kościót naszym domem i szkoła komunii. Program duszpasterski dla Kościoła w Polsce na lata 2010-2013. Rok 2011/2012. Red. Sz. S t u ł k o w s k i. Poznań 2011 s. 9.
} 
ujęciu normatywnym, następnie w ujęciu realizowanym, aby dojść do wniosków pastoralnych (ujęcie postulowane) ${ }^{4}$.

\section{Podstawy teologiczno-prawne działalności DRD}

Z woli Chrystusa główną osobą odpowiedzialną za posługę nauczania, uświęcenia i kierowania Ludem Bożym w diecezji jest biskup. W myśl nauczania II Soboru Watykańskiego, biskupi kieruja powierzonymi sobie poszczególnymi Kościołami jako zastępcy i legaci Chrystusa radami, zachętami i przykładem, ale także moca swego autorytetu i świętej władzy (...), która w imieniu Chrystusa sprawuja. Władza ta jest własna, zwyczajna i bezpośrednia (KK 27). Sprawując swoją władzę, mają oni korzystać ze zdania wiernych. Ujawnianie przez wiernych swojego zdania może posiadać formę instytucjonalną, czyli odbywać się w ramach DRD, będącej ważnym organem konsultacyjnym działającym w diecezji.

Idea DRD powstała po II Soborze Watykańskim jako odpowiedź na wzrastającą rolę apostolstwa świeckich oraz pogłębiającą się świadomość odpowiedzialnego i świadomego udziału różnych stanów Kościoła w realizacji jego misji. Wszyscy ochrzczeni stanowią Lud Boży i są wezwani do wzięcia odpowiedzialności za Kościól ${ }^{5}$. Tego typu rada powinna istnieć w każdej diecezji, o czym mówi Dekret o pasterskich zadaniach biskupów w Kościele Christus Dominus II Soboru Watykańskiego, gdzie podkreśla się, że jej zadaniem jest badanie i rozważanie tego wszystkiego, co odnosi się do działalności duszpasterskiej oraz wyciaganie z tego praktycznych wniosków (DB 27). Ustanowieniu DRD w diecezji domaga się wielość i złożoność współczesnych problemów duszpasterskich, które można rozwiązywać przy udziale wiernych po wieloaspektowej analizie ${ }^{6}$.

Konkretne wskazania dotyczące powoływania i działalności DRD zawiera KPK w kanonach 511-514. Powinna ona być ustanowiona w każdej diecezji (KPK 511), a powołani do niej mogą być tylko wierni pozostający w pełnej łączności z Kościołem katolickim, duchowni i członkowie instytutów życia konsekrowanego, a przede wszystkim świeccy (KPK kan. $512 \S 1$ ). To właśnie oni mają możność, a nawet niekiedy obowiązek, ujawniania swojego zdania w sprawach, które dotyczą ich potrzeb duchowych, życzeń i dobra Kościoła (KPK kan. $212 \S 2-3)$. Ustawodawcy zależało na tym, aby w radzie swój udział mieli kato-

${ }^{4}$ Por. R. K a m i ń s k i: Metody teologii pastoralnej. W: Teologia pastoralna. Red. R. K a m i ńs k i. Lublin 2000 s. 24-26.

${ }^{5}$ J. W r o c eń s k i: Diecezjalna Rada Duszpasterska - struktura i zadania. W: Struktury kolegialne w Kościele partykularnym. Materiały z ogólnopolskiej konferencji naukowej zorganizowanej przez Stowarzyszenie Kanonistów Polskich. Wydziat Nauk Prawnych TN KUL i Wyższe Seminarium Duchowne w Tarnowie. Tarnów 2004. Red. J. K r u k o w s k i, T. R o z k r u t. Tarnów 2004 s. 110-112.

${ }^{6}$ Por. tamże, s. 114. 
licy świeccy, co wiąże się z odnowioną eklezjologią II Soboru Watykańskiego ${ }^{7}$. Sposób wyboru członków rady powinien dokonywać się według kryteriów reprezentatywności, kompetencji i przydatności (KPK kan. $512 \S 2$ ). KPK podkreśla, że do rady należy dobierać tylko tych wiernych, którzy odznaczają się pewną wiarą, dobrymi obyczajami i roztropnością (KPK kan. 512 § 3). DRD powinna mieć własny statut wydany przez biskupa diecezjalnego, w którym będzie określona jej natura, cel, sposób powoływania członków, ich liczba, czas trwania kadencji ${ }^{8}$. DRD, mająca jedynie głos doradczy, powinna być zwoływana przez biskupa przynajmniej raz w roku (KPK kan. 514). Powinien on konsultować z radą swoje ważniejsze decyzje $\mathrm{w}$ sprawach duszpasterskich, nie lekceważąc mądrych i roztropnych ocen, wniosków i sugestii. Nie przekreśla to autonomii urzędu biskupiego, wpływając na bardziej demokratyczny charakter podejmowanych decyzji oraz na podmiotowe traktowanie Ludu Bożego ${ }^{9}$. Przebieg posiedzenia rady powinien być protokołowany przez sekretarza rady lub specjalnego protokolanta ${ }^{10}$.

Kodeks nie definiuje szczegółowo spraw którymi powinna się zajmować DRD, podkreślając w ogólny sposób, że ma badać pod władza biskupa wszystko, co dotyczy działalności pasterskiej, a także rozważać i przedstawiać praktyczne wnioski (KPK kan. 511). Rodzi to przypuszczenia, że prawodawca zasugerował, aby szczegółowe ustalenia uwzględniające specyfikę i sytuację duszpasterską danej diecezji znalazły się w poszczególnych statutach ${ }^{11}$. Tematykę zajęć rady uszczegóławia Dyrektorium o pasterskiej posłudze biskupów Apostolorum successores (dalej AS). Pisząc o zadaniach DRD, dokument zwraca uwagę na to, że ma ona pod przewodnictwem biskupa przedyskutować określone zagadnienia dotyczące działalności duszpasterskiej, przykładowo zaliczając do nich kwestię programu duszpasterskiego, diecezjalnych inicjatyw misyjnych, katechetycznych $i$ apostolskich, odpowiednich środków stużacych pogłębianiu formacji doktrynalnej $i$ życia sakramentalnego wiernych, sposobów ułatwiania pracy duszpasterskiej duchownych czy uwrażliwiania opinii publicznej na problemy Kościoła ${ }^{12}$. Mówiąc o bardziej skutecznym działaniu, w dokumencie proponuje się, aby obrady poszczególnych sesji były poprzedzane odpowiednim studium przygotowawczym przygotowanym z pomocą instytucji i urzędów pastoralnych diecezji (por. AS 185).

7 Por. T. P a w l u k: Prawo kanoniczne wedlug kodeksu Jana Pawła II. T. 2. Lud Boży jego nauczanie i uświęcanie. Olsztyn 1986 s. 252-253.

${ }^{8}$ Por. J. Wro c eń s k i, dz. cyt., s. 124.

${ }^{9}$ Por. tamże, s. 123.

${ }^{10}$ Por. T. P a w 1 u k, dz. cyt., s. 254.

${ }^{11}$ Por. J. W r o c e ń s k i, dz. cyt., s. 116.

${ }^{12}$ Kongregacja ds. Biskupów: Dyrektorium o pasterskiej posłudze biskupów Apostolorum successores. Watykan 2004 nr 185. 
Mówiąc o działalności DRD, należy także odwołać się do adhortacji apostolskiej Jana Pawła II Christifideles laici. Adhortacja, przypominając nauczanie Dekretu o apostolstwie świeckich Apostolicam actuositatem II Soboru Watykańskiego o czynnym udziale wiernych świeckich w życiu Kościoła partykularnego (por. DA 10), podkreśla rolę i znaczenie ich uczestnictwa w DRD. Według adhortacji, udział świeckich w pracach rady ma pozwolić na rozszerzenie zakresu konsultacji oraz szersze i odważniejsze stosowanie zasady współpracy, która w pewnych przypadkach ma charakter decyzyjny (por. ChL 25).

Po przedstawieniu teologiczno-prawnych wskazań działalności DRD zostaną ukazane wyniki badań dotyczące tego, jak są one realizowane w praktyce. Dzięki temu możliwe będzie wyciągnięcie wniosków i adekwatnych do nich postulatów.

\section{Metodologia badań}

Koncepcja badań została oparta na przytoczonych wcześniej dokumentach Kościoła, które stanowiły podstawę teoretyczną do stworzenia narzędzi badawczych. Zawierają one sformułowania dotyczące sposobów powołania rady, jej składu, kadencji, form zwoływaniu i przekazanych kompetencji. Jest to fundament do operacjonalizacji ${ }^{13}$ pojęć związanych $\mathrm{z}$ funkcjonowaniem DRD. Warto w tym miejscu podkreślić udział ks. abp S. Gądeckiego, który nie tylko był inspiratorem badań i ułatwił ich przeprowadzenie, lecz także wniósł własne merytoryczne sugestie.

Najpierw została skierowana do każdej Kurii Biskupiej prośba o przesłanie następujących materiałów:

- statutów DRD (ze względu na duży poziom ogólności tych wskazań, każda diecezja opracowała własny statut DRD, według którego zorganizowane jest funkcjonowanie rad);

- kopii protokołów zebrań DRD z dwóch ostatnich lat;

- listy członków DRD (z uwzględnieniem: środowiska reprezentowanego, stanu, imienia i nazwiska oraz adresu do korespondencji).

Na prośbę skierowaną do wszystkich polskich diecezji, odpowiedź spłynęła z 31, w tym 21 diecezji przesłało kompletny ich zestaw, czyli statut, kopię protokołów oraz listę członków. $Z$ dokumentów wynikało, że DRD działają w 26 pol-

${ }^{13}$ Operacjonalizacja to zabieg metodologiczny polegający na przeprowadzeniu próby określenia (zdefiniowania) przedmiotu badań w taki sposób i w takim zakresie, aby było możliwe stwierdzenie jego występowania i/lub natężenia. Inaczej mówiąc, operacjonalizacja polega na stworzeniu konkretnych procedur badawczych (operacji), które pozwolą na dokonanie empirycznych obserwacji odpowiadających tym pojęciom w świecie rzeczywistym - zob. E. B a b bi e: Podstawy badań społecznych. Warszawa 2009 s. 132. 
skich diecezjach ${ }^{14}$. Wiele braków w korespondencji związanych było ze zmianami biskupów ordynariuszy, co spowodowało, że nie odbywały się spotkania DRD. Na dalszym etapie procedowania została przeanalizowana treść przesłanych dokumentów. Szukano odpowiedzi na pytania, w jakim stopniu statuty DRD realizują nauczanie Magisterium Kościoła oraz czy treść zawarta w protokołach ze spotkań DRD świadczy o realizacji tych statutów i uwzględnianiu znaków czasu. Niestety, zdarzały się sytuacje, że DRD funkcjonowała mimo braku statutów, do których uchwalenia zobowiązuje prawo kanoniczne (KPK kan. 513 $\S 1)$. Inny przypadek, który pojawił się kilkakrotnie podczas analizy treści statutów, to kopiowanie dokumentów z innych diecezji. Skrajnością było powoływanie się diecezji będącej sufraganią na statuty obowiązujące w diecezji metropolitalnej, w której takowych dokumentów nie ma.

$\mathrm{Na}$ listach członków DRD przesłanych do analizy znalazły się 994 osoby, z czego 53,3\% stanowili kapłani, 39,6\% osoby świeckie i 7,1\% przedstawiciele stanu zakonnego. Widoczna jest tutaj dysproporcja w liczbie uczestników DRD różnych stanów.

\section{Członkowie DRD wg stanów}

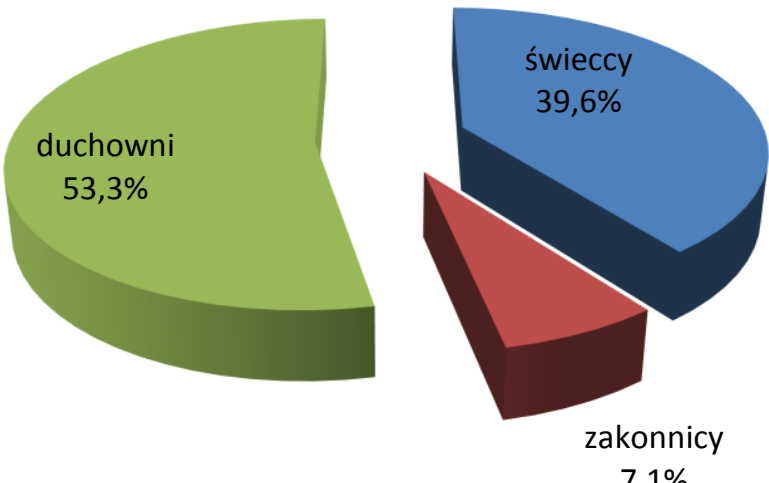

Wyk. 1. Rozkład stanów według nadesłanych list członków DRD.

\footnotetext{
${ }^{14}$ Należą do nich następujące archi(diecezje): częstochowska, drohiczyńska, gliwicka, gnieźnieńska, kaliska, katowicka, kielecka, koszalińsko-kołobrzeska, krakowska, legnicka, łowicka, łódzka, opolska, płocka, poznańska, przemyska, rzeszowska, siedlecka, sosnowiecka, świdnicka, tarnowska, toruńska, warszawska, wrocławska, zamojsko-lubaczowska, zielonogórsko-gorzowska. W tych diecezjach ostatecznie przeprowadzono badania. Autorzy po różnych konsultacjach przyjęli założenie, że skoro pozostałe diecezje nie nadesłały dokumentów, to DRD w nich nie funkcjonują.
} 
Następnie, z utworzonej bazy wszystkich członków DRD, metodą doboru celowo-losowego, została wybrana reprezentacyjna grupa respondentów. W pierwszej połowie 2012 r. do 12 osób z każdej DRD zostały przesłane pocztą kwestionariusze. Ankieta dotyczyła prezentacji i oceny form pracy DRD. Zawierała 15 pytań, z czego 3 miały charakter otwarty, gdzie respondenci mogli wpisać własne przemyślenia. Autorów interesowało, jaka problematyka jest podejmowana w czasie spotkań DRD, jaki jest sposób ich organizacji i przebiegu oraz jakie mają własne propozycje dotyczące ich funkcjonowania.

Z 312 wysłanych ankiet, do badaczy wróciło wypełnionych 131. Poziom $42,0 \%$ zwrotów jest wystarczający dla metody pocztowej, by na tej podstawie tworzyć uogólnienia dla całej badanej populacji. Autorzy czynili to jednak w sposób roztropny, mając świadomość, że znaczna część diecezji nie jest reprezentowana w niniejszym badaniu. Większą uwagę natomiast zwrócili na opis działania DRD w konkretnych diecezjach, których członkowie wypowiedzieli się poprzez ankietę. Tutaj zadanie było nieco utrudnione, gdyż widoczne są istotne dysproporcje między liczbą zwrotów z poszczególnych diecezji. Najwięcej ankiet odesłano $z$ archidiecezji przemyskiej (9) i warszawskiej (8). Były także takie diecezje, z których członkowie odesłali jedynie 3 ankiety z 12 wysłanych. Autorzy starali się więc ostrożnie podchodzić do zebranego materiału, tym niemniej udało się na tej podstawie stworzyć kilka uogólnień, które dla badaczy są istotne i wartościowe do ewaluacyjnej analizy obecnego funkcjonowania DRD. Prezentacja danych liczbowych w niniejszym raporcie zostanie uzupełniona autentycznymi wypowiedziami członków DRD, zamieszczonymi w odpowiedziach otwartych ankiety. Da to pełniejszy obraz rzeczywistości, której się przyglądamy, a także będzie wyrazem ich zatroskania o dobro wspólnoty Kościoła. Niech poniższy cytat z wypowiedzi osoby duchownej z diecezji w centralnej Polsce będzie myślą przewodnią prowadzonych rozważań: Ankieta ukazuje prawdę o nieco fikcyjnej roli DRD. Potrzeba ożywienia i zmian. Oby ta ankieta stała się inspiracją do rzetelnego potraktowania tegoż gremium.

\section{Analiza treści dokumentów DRD}

Jak zostało to wcześniej opisane, badanie składało się z dwóch modułów, skierowanych do różnych podmiotów DRD. Najpierw została skierowana prośba do Kurii Biskupich o przesłanie wskazanych dokumentów. Na ich podstawie badacze dokonali całościowej analizy ich treści. W pierwszej kolejności zajęto się zgodnością tych dokumentów z wytycznymi Magisterium. W sposób szczególny zwrócono uwagę na statuty DRD, w których powinny być jasno określone cele i zadania. Mają one nadawać kierunek działań.

Z trzech celów wymienionych przez Magisterium, w statutach DRD wskazuje się najczęściej na postulowanie rozwiązań duszpasterskich, niekoniecznie po- 
przedzając je badaniem rzeczywistości i rozważaniem aktualnych problemów. Można domniemywać, że zasadniczo statuty nie zakładają, by zgłaszane propozycje były poprzedzone odpowiednią ich analizą.

Następnie, w tych samych dokumentach przeanalizowano zadania, które ma realizować DRD i skonfrontowano je z wytycznymi Magisterium.

Z pięciu głównych zadań polecanych przez Magisterium do dyskusji w ramach DRD (program duszpasterski; diecezjalne inicjatywy misyjne, katechetyczne i apostolskie; środki służące pogłębianiu formacji doktrynalnej i życia sakramentalnego wiernych; sposoby ułatwiania pracy duszpasterskiej duchownych; uwrażliwianie opinii publicznej na problemy Kościoła) statuty najczęściej zwracają uwagę na przygotowanie programu duszpasterskiego, omówienie różnych inicjatyw oraz ułatwianie pracy duchownych. W marginalnym stopniu, według statutów, DRD stawia sobie zadania związane $\mathrm{z}$ formacją i uwrażliwianiem opinii publicznej na problemy Kościoła. $Z$ tego można dedukować, że statuty większą uwagę poświęcają działaniom ad extra niż w obrębie Kościoła instytucjonalnego ad intra.

Autorzy, na podstawie treści statutów, skonstruowali skalę ich zgodności z Magisterium. Okazało się, że co czwarta diecezja pozostaje na średnim poziomie zgodności, zaś na wysokim jedna na dziesięć. Niski poziom tej zgodności dotyczy przynajmniej co piątej przebadanej diecezji. To nie jedyne wnioski, które można wysnuć po analizie otrzymanych dokumentów.

Mówiąc o działaniu zorganizowanym, także w obrębie Kościoła, należy najpierw ustalić cele, które mają nadawać kierunek działań. Dopiero na ich podstawie precyzuje się zadania do realizacji i ustala plany działania ${ }^{15}$. W wielu statutach ten porządek, wypływający zarówno ze zdrowego rozsądku, jak i poparty teorią prakseologiczną, nie jest zachowany. Niekiedy cele i zadania znajdują się w dokumentach, ale w nieodpowiedniej konfiguracji, mieszając swoje zakresy pojęciowe. Problem języka dotyczy także sposobu wyrażania myśli w dokumen-

${ }^{15}$ Chociaż Kościół ma religijny i nadprzyrodzony charakter, to jednak składa się z ludzi, którzy w jakimś stopniu podlegają zasadom organizacji i zarządzania. Powinny one być również uwzględniane przy podejmowaniu każdej działalności duszpasterskiej, oczywiście z zachowaniem specyfiki instytucji Kościoła (zob. RH 21). Jednym z głównych zagadnień poruszanych przez nauki prakseologiczne jest problematyka celów. Mają one kluczowe znaczenie dla skuteczności działań każdej organizacji. Zapewniają poczucie kierunku, wpływają na planowanie działań, mogą być źródłem motywacji, dla pracowników, dają skuteczny mechanizm oceny i kontroli. Chociaż nie można zaplanować bezpośredniego głównego celu działań Kościoła (wzrost w wierze, nadziei i miłości), gdyż zależy od łaski Boga, to jednak można planować cele pośrednie, które zawsze mają prowadzić do realizacji celu głównego - zob. R. K a m i ń s k i: Duszpasterstwo jako działalność zorganizowana. W: Teologia pastoralna, dz. cyt., s. 423; 436; J. M a ri án s ki: Żyć parafią. Wrocław 1984 s. 31-33; R. W. G r i f f i n: Podstawy zarządzania organizacjami. Warszawa 1997 s. $200-201$. 
tach. Są one często ogólne, niejasne i mało konkretne, co zauważa się także w innych dokumentach Magisterium. Wszystkie te spostrzeżenia, dotyczące formy redagowania statutów, mają w konsekwencji swoje przełożenie na owocność działań DRD.

Po analizie nadesłanych statutów wydaje się, że część z nich ma słabe umocowanie w nauczaniu Magisterium. Pomimo tego, że trudno znaleźć w nich wyraźnie zarysowane cele i zadania, poruszają one inne kwestie, jak określenie stanu religijności diecezjan czy też posługi duszpasterskiej. Należy przypomnieć, że statut DRD jest jej dokumentem programowym, który powinien uwzględniać główne kierunki i metody działań, a nie ograniczać się do bieżących spraw.

Nieco lepiej wygląda realizacja zadań wyznaczonych przez Magisterium. Analiza protokołów z posiedzeń DRD pokazała, że zazwyczaj są one głównym przedmiotem spotkań.

Z protokołów DRD wynika, że na spotkaniach są podejmowane przede wszystkim kwestie związane z inicjatywami misyjnymi, katechetycznymi i apostolskimi oraz formacją doktrynalną i ożywianiem życia sakramentalnego. Najrzadziej podejmuje się kwestie związane $\mathrm{z}$ uwrażliwianiem opinii publicznej na problemy Kościoła. Zestawiając te dane z treścią statutów, zauważyć należy, że w pewnym stopniu różnią się one pod względem wyznaczanych i realizowanych zadań. Najbardziej jest to widoczne w kontekście przygotowywania programu duszpasterskiego.

Magisterium Kościoła nie uwzględnia wszystkich zadań, którymi ma się zajmować DRD, zwracając uwagę na odczytywanie znaków czasu i uwarunkowań pracy Kościoła lokalnego. Autorzy te kwestie ujęli w postaci 6 aspektów, których praca DRD może i powinna dotknąć.

Czytając protokoły DRD można wydedukować, że na spotkaniach są poruszane przede wszystkim zagadnienia związane z życiem religijnym wspólnoty diecezjalnej. Połowa DRD podejmowała także kwestie społeczne i moralne. Najrzadziej członkowie DRD zajmowali się kwestiami finansowymi i politycznymi. $Z$ jednej strony, właściwym jest podejmowanie przez DRD przede wszystkim spraw związanych z życiem religijnym diecezji. Z drugiej jednak strony, dostrzega się zbyt małe zaangażowanie DRD w podejmowaniu innych kwestii.

Treść protokołów pokazuje, iż większość DRD realizuje minimum częstotliwości spotkań wskazane przez Magisterium. Nieco ponad połowa przebadanych DRD spotyka się na posiedzeniach raz w roku, natomiast prawie co czwarta gromadzi się częściej. Niestety - aż 1/3 diecezji nie przesłała wystarczających dokumentów, by stwierdzić, jak często spotyka się jej DRD. Opierając się na otrzymanych protokołach, można stwierdzić, że zasadniczo DRD spełniają minimum formalne, zawarte w KPK kan. $514 \S 2$. 
Podsumowując zebraną na podstawie protokołów wiedzę o działalności DRD, należy zauważyć, że niekiedy zajmują się one czymś innym, niż powinny się zajmować w świetle wskazań Magisterium, na przykład przybierając formę rad kapłańskich. $Z$ drugiej jednak strony należy także zauważyć ciekawe inicjatywy podejmowane $w$ diecezjach inspirowane $i$ organizowane $w$ ramach prac DRD, o których nie wspomina Magisterium.

Materiały uzyskane od diecezji zostały poddane analizie treści. Na ich podstawie stworzono wskaźniki oparte na wytycznych zawartych w Magisterium Kościoła. Pozwoliło to stwierdzić stopień zgodności treści w nich zawartych z przedstawionymi wcześniej wskazaniami Magisterium. Wzięto pod uwagę liczbę nadesłanych dokumentów, cele i zadania określone w statutach DRD, odpowiedź na odczytane znaki czasu, częstotliwość spotkań i reprezentatywność członków. Różne poziomy tej adekwatności pozwoliły wyodrębnić kategorie diecezji ${ }^{16}$. Pierwszym uwzględnionym przez badaczy parametrem była liczba nadesłanych dokumentów. Świadczy ona o uporządkowaniu spraw związanych z organizacją i przebiegiem pracy DRD, co ma wpływ na efektywności jej działań. Zwrócono też uwagę na cele $i$ zadania umieszczone w statutach DRD, które winny tam się znaleźć po to, aby nie tylko zachować wierność duchowi Magisterium, ale również nadać kierunek podejmowanym pracom. Jeżeli chodzi o zadania podejmowane przez DRD, to protokoły, których forma jest bardzo zróżnicowana, zawierają ich wieloraki opis. Badacze w sposób szczególny zwrócili uwagę na te, które odwołują się do wskazań Magisterium. Zwrócono też uwagę na znaki czasu, jakie ma odczytywać DRD. Zanalizowano również częstotliwość spotkań DRD, która jest jednym z elementów świadczących o sposobie pracy. Na jej podstawie można dedukować o zaangażowaniu DRD w prace diecezji. Podstawą określenia częstotliwość spotkań były liczba protokołów z ostatnich dwóch lat. Zwrócono także uwagę na reprezentatywność członków, co wyraźnie podkreśla prawo kanoniczne, apelując aby rada składała się z przede wszystkim świeckich (KPK kan. $512 \S 1)$.

Wymienionym wyżej wskaźnikom zostały przyporządkowane odpowiedniej rangi punkty, w zależności od ich znaczenia dla ogólnego poziomu zgodności dokumentów DRD z wytycznymi Magisterium. Tak przeanalizowane dokumenty diecezji pozwoliły każdą z nich przyporządkować do odpowiedniej kategorii. Do pierwszej kategorii zaliczono diecezje, które osiągnęły minimum 75,0\% najwyższej uzyskanej liczby punktów, co świadczy o bardzo dużym stopniu zgodności ich dokumentów z Magisterium. Diecezje, których poziom zgodności dokumentów z Magisterium wyniósł między 50,0\% a 75,0\% tworzą kategorię duży poziom

\footnotetext{
${ }^{16}$ Badacze punktowali poszczególne elementy Magisterium, które znalazły się w dokumentach rad, nadając im odpowiednią rangę. Na tej podstawie każda diecezja otrzymała odpowiednią ilość punktów, które zaprezentowane na skali pozwoliły stworzyć odpowiednie kategorie diecezji pod względem zgodności ich dokumentów z wytycznymi zawartymi w Magisterium.
} 
zgodności. Kategorię średni poziom zgodności przyporządkowano diecezjom, w których dokumenty spełniają między $25,0 \%$ a 50,0\% określonych wymagań. Wszystkie inne diecezje zostały zaliczone do kategorii niski poziom zgodności. Taka kategoryzacja pozwala na bardziej obrazowe ukazanie charakterystyki ogólnej DRD w Polsce ${ }^{17}$.

\section{Prezentacja wyników badań czlonków DRD}

Autorzy, dokonując analizy odpowiedzi w kwestionariuszach adresowanych do członków DRD, pragną na podstawie ich wypowiedzi odpowiedzieć na cztery pytania związane z działalnością DRD w teraźniejszości i przyszłości.

\section{Jakie kwestie podejmuje DRD na spotkaniach?}

Respondenci zapytani, czy rada bada wszystko, co dotyczy działalności duszpasterskiej, w większości odpowiadali twierdząco (60,3\%), choć przeważająca liczba skłaniała się ku odpowiedzi „raczej tak” (47,3\%). Spory odsetek respondentów odpowiedział przecząco $(28,3 \%)$.

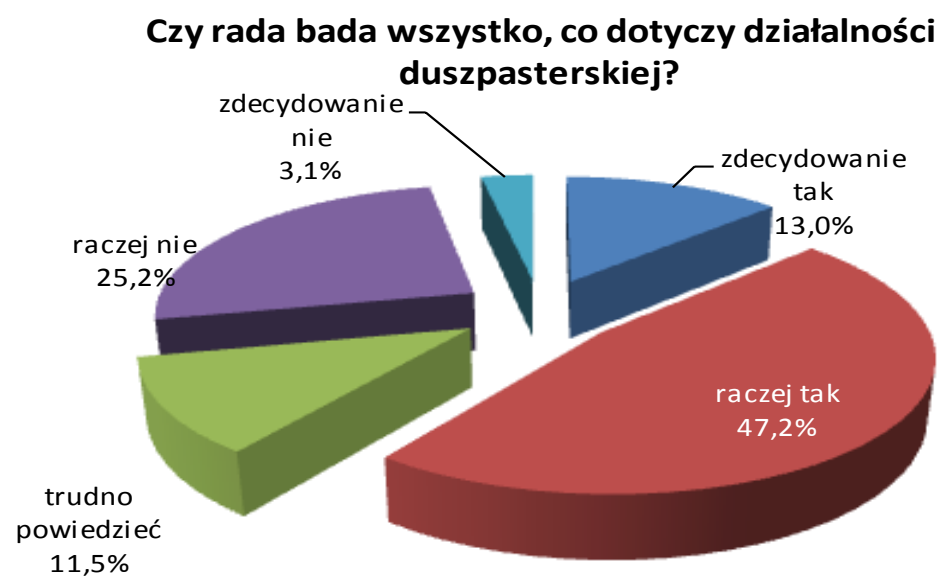

Wyk. 2. Opinia członków rady dotycząca zakresu badań DRD w kontekście duszpasterskim.

${ }^{17}$ Autorzy zdają sobie sprawę, że czytelnik oczekuje wskazania konkretnych diecezji, jednak świadomie nie ujawniają ich nazw, gdyż artykuł ma pokazać ogólną sytuację DRD w Polsce. W pracy przyjęto założenie ujawniania nazw diecezji w kontekście pozytywnych form działalności ich DRD. Ma to stać się punktem odniesienia dla pracy rad w tych diecezjach, gdzie nie funkcjonują one właściwie bądź dopiero będą tworzone. 
Z kolei na pytanie dotyczące zajmowania się przez DRD innymi sprawami, istotnymi dla Kościoła lokalnego, aż $3 / 5$ badanych odpowiedziało twierdząco $(60,3 \%)$. Podobny jak poprzednio odsetek $(26,4 \%)$ nie zauważył w działalności DRD podejmowania tego typu kwestii.

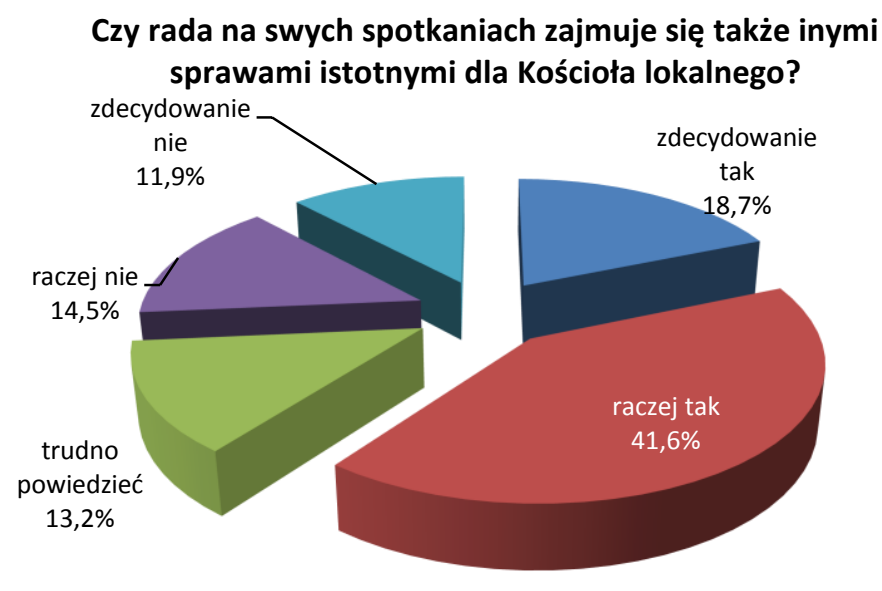

Wyk. 3. Opinia członków rady dotycząca podejmowania przez DRD istotnych spraw dla Kościoła lokalnego.

Gdy zapytano respondentów, czy omawiane kwestie są adekwatne do wyzwań współczesności, aż 73,6\% odpowiedziało twierdząco, przy czym należy zauważyć, że znaczną część stanowiły odpowiedzi „zdecydowanie tak” (31,4\%). Oczywistym więc jest, że jednocześnie mniejszy jest odsetek osób, które odpowiedziały przecząco na to pytanie $(13,1 \%)$. 


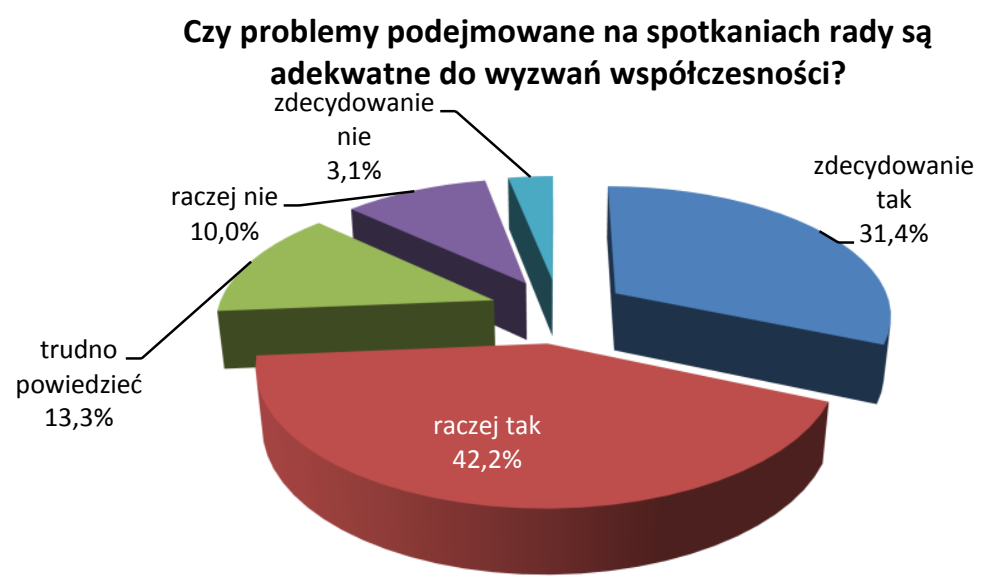

Wyk. 4. Opinia członków rady dotycząca adekwatności działań DRD wobec wyzwań współczesności.

Przyglądając się odpowiedziom na zadane pytania o ogólną tematykę spotkań DRD, dostrzec można dwie istotne prawidłowości. Kategoria odpowiedzi „trudno powiedzieć” pojawia się przy każdym pytaniu na podobnym, dość wysokim poziomie. Może to świadczyć o braku umiejętności umiejscowienia podejmowanej problematyki w kontekście sformułowań zawartych w kwestionariuszu i zaczerpniętych z Magisterium Kościoła. Potwierdza to drugie spostrzeżenie mówiące o tym, że respondenci najbardziej pozytywnie oceniali zaangażowanie DRD w kwestie dotyczące wyzwań współczesności, czyli pojęcia zrozumiałego dla każdego członka, bez względu na wiedzę teologiczną. Taki stan rzeczy może mieć dwie przyczyny: $\mathrm{z}$ jednej strony język dokumentów Magisterium jest nieraz zbyt ogólnikowy i hermetyczny, z drugiej zaś członkowie DRD nie posiadają odpowiedniej formacji teologicznej.

Biorąc pod uwagę odpowiedzi respondentów dotyczące ogólnego ujęcia tematyki spotkań DRD, ich praca jawi się jako zgodna z wytycznymi Magisterium. Należy jednak postawić pytanie o ocenę przez respondentów zaangażowania rady w poszczególne dziedziny sugerowane przez Magisterium.

Na skali stopnia zaangażowania żadna z podjętych kwestii, zdaniem respondentów, nie wywoływała dla większości bardzo dużego zaangażowania. „Duże zaangażowanie" rady budziły takie kwestie, jak: inspirowanie inicjatyw apostolskich, proponowanie działań ożywiających życie sakramentalne oraz uwrażliwianie opinii publicznej na problemy Kościoła. Odpowiedź „średnie zaangażowanie" respondenci najczęściej zaznaczali przy: tworzeniu programu duszpaster- 
skiego, proponowaniu działań dotyczących formacji doktrynalnej oraz inspirowaniu inicjatyw katechetycznych. Na ,słabe zaangażowanie” badani wskazywali najczęściej przy kwestiach dotyczących inspirowania inicjatyw misyjnych. Żadna $\mathrm{z}$ zamieszczonych powyżej dziedzin nie była $\mathrm{w}$ większości oceniona $\mathrm{w}$ kategoriach „brak zaangażowania” bądź „bardzo słabe zaangażowanie”. Należy jednak zwrócić uwagę na to, że przy inspirowaniu inicjatyw misyjnych aż co piąty badany zauważył brak zaangażowania rady. Kategoria ,inne” kumulowała przede wszystkim odpowiedzi ,średnie zaangażowanie” i „słabe zaangażowanie”.

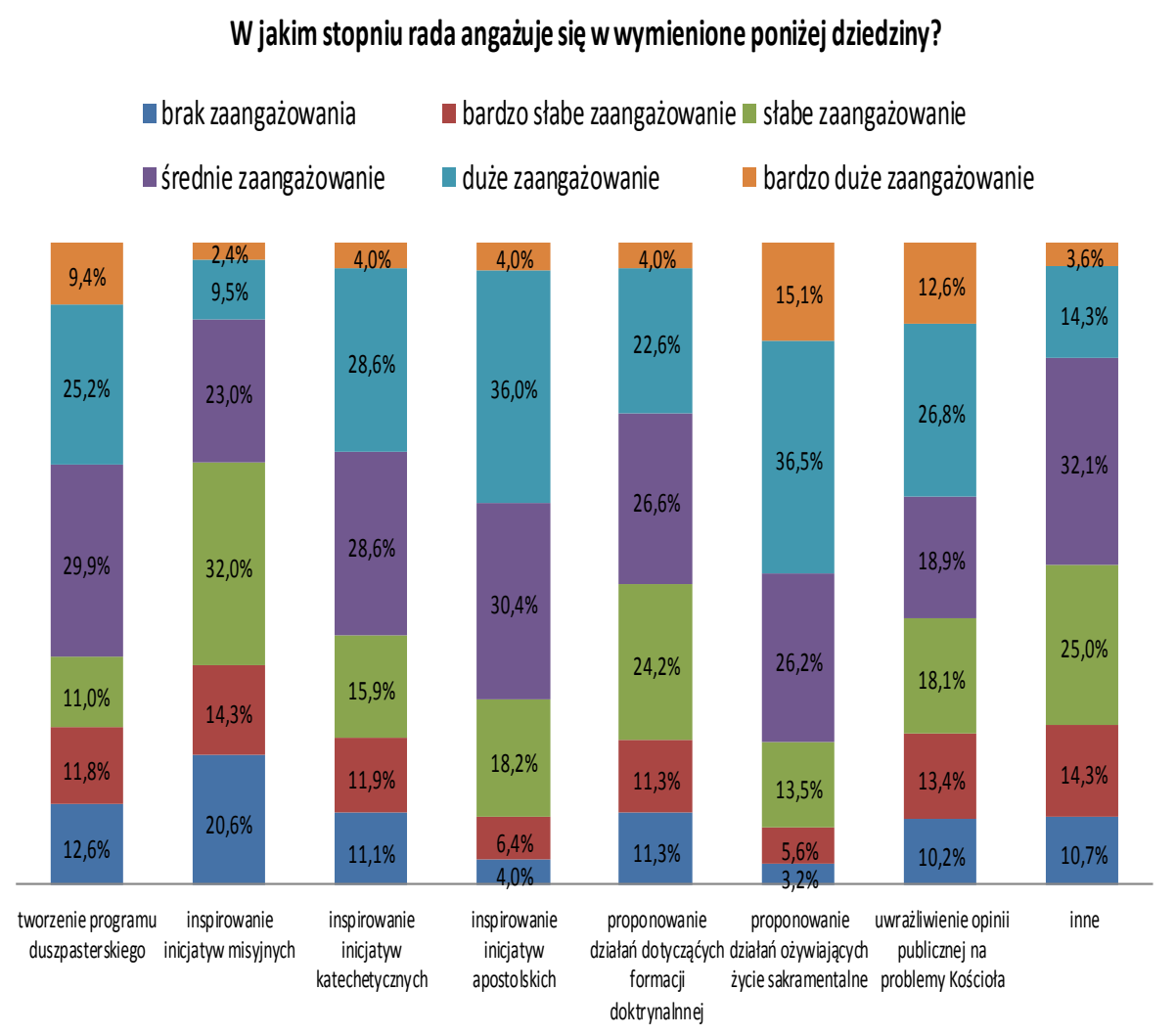

Wyk. 5. Stopnie zaangażowania DRD w poszczególne dziedziny pracy wskazane przez Magisterium.

Uzyskane odpowiedzi członków DRD mogą świadczyć o tym, że rady nie podejmują w sposób kompleksowy wszystkich zadań wskazywanych przez Magisterium. Co wpływa na taki stan rzeczy? Warto zwrócić uwagę na dwie ten- 
dencje, które mogą mieć tu znaczenie. Może to wynikać ze słabej znajomości Magisterium, ewentualnie braku umiejętności przekładania wskazań Kościoła na uwarunkowania lokalne. $Z$ drugiej strony, istnieje obawa, że obrady DRD determinują aktualne wydarzenia i brakuje czasu na refleksję na temat płaszczyzn działalności, wyznaczonych radom przez Magisterium.

\section{Jaki jest sposób pracy DRD?}

Zapytano także respondentów o to, czy rada proponuje praktyczne rozwiązania podejmowanych problemów? $2 / 3 \mathrm{z}$ nich odpowiedziało pozytywnie na to pytanie $(66,2 \%)$. Kilkunastoprocentowe odpowiedzi zawierały stwierdzenia ,trudno powiedzieć” $(16,9 \%)$ i „raczej nie” $(14,6 \%)$.

\section{Czy rada proponuje praktyczne rozwiązania podejmowanych problemów?}

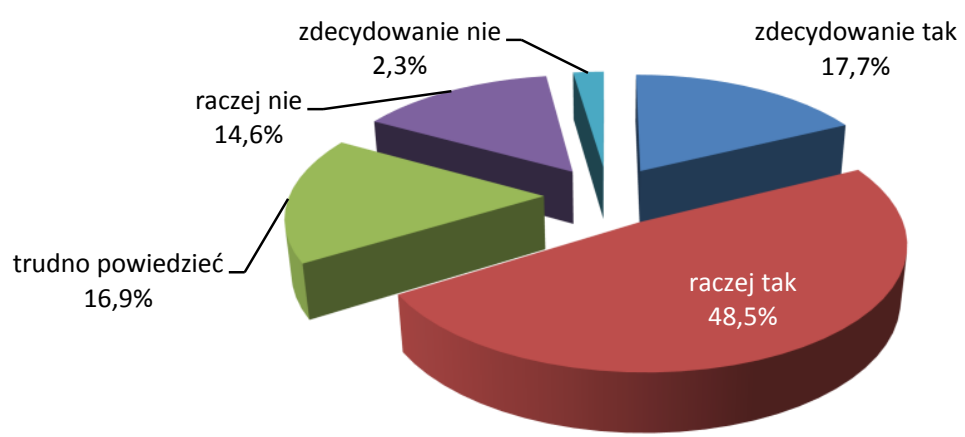

Wyk. 6. Opinia członków rady dotycząca propozycji rozwiązań praktycznych proponowanych przez DRD.

Nieco inaczej prezentuje się kwestia oceny respondentów dotyczącej uwzględniania w działalności duszpasterskiej wniosków wypracowywanych przez DRD. Tutaj najczęściej pojawiała się odpowiedź „trudno powiedzieć” $(39,2 \%)$ i ,raczej tak” $(31,5 \%)$. Zdecydowanie potwierdziło to $18,5 \%$ badanych. 


\section{Czy wnioski wypracowane przez radę są uwzględniane w działalności duszpasterskiej?}

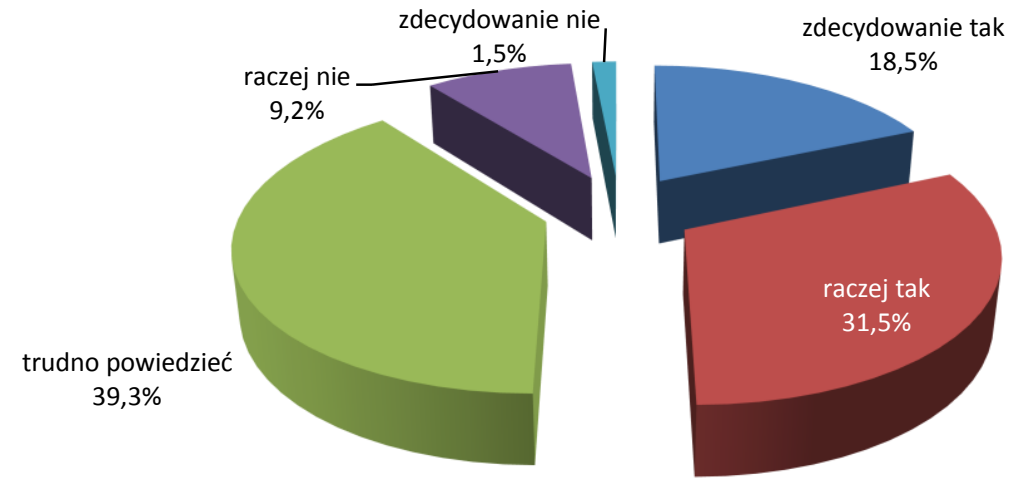

Wyk. 7. Opinia członków rady dotycząca uwzględniania w działalności duszpasterskiej owoców pracy DRD.

Zauważyć należy, że respondenci bardziej pozytywnie oceniają propozycje praktycznych rozwiązań podejmowanych problemów, które wypracowuje rada, niż ich późniejsze uwzględnianie w pracy duszpasterskiej. Warto w tym miejscu przywołać wypowiedź jednego z respondentów: Odnoszę wrażenie, że rada nie ma rzeczywistego wptywu na ksztaltowanie duszpasterstwa diecezji. Na zebraniach rady przedktada się do oceny już wcześniej wypracowane propozycje duszpasterskie, a decyzja o tym, że zostana one wprowadzone $w$ życie już zapadła. Wydaje się, że jedną z przyczyn takiego stanu rzeczy jest pojawiająca się w kościelnych kręgach fasadowość. Język polski tym pojęciem określa: stwarzanie pozorów, w tym przypadku dotyczących podmiotowego traktowania osób świeckich.

A jak wygląda kwestia wprowadzania członków w podejmowanie zagadnienia? Zdecydowana większość badanych potwierdziła, że w jakiś sposób jest wcześniej wprowadzana w podejmowane przez DRD zagadnienia $(86,7 \%)$. 


\section{Czy członkowie rady są wprowadzani w podejmowane zagadnienia przez odpowiednie przygotowanie?}

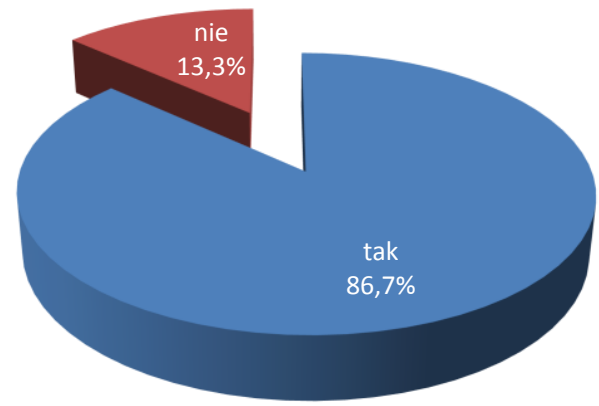

Wyk. 8. Opinia członków rady na temat odpowiedniego przygotowania prac DRD.

Najczęściej wśród tych sposobów wymieniano: „powiadamianie o tematyce następnego spotkania" (77,3\%), „prezentacja przez prowadzącego zebranie” $(60,9 \%)$ i ,wcześniejsze przesyłanie materiałów" $(58,2 \%)$. 42,7\% wspomniało o „wprowadzeniu eksperta”.

\section{W jaki sposób członkowie są wprowadzani do prac rady?}

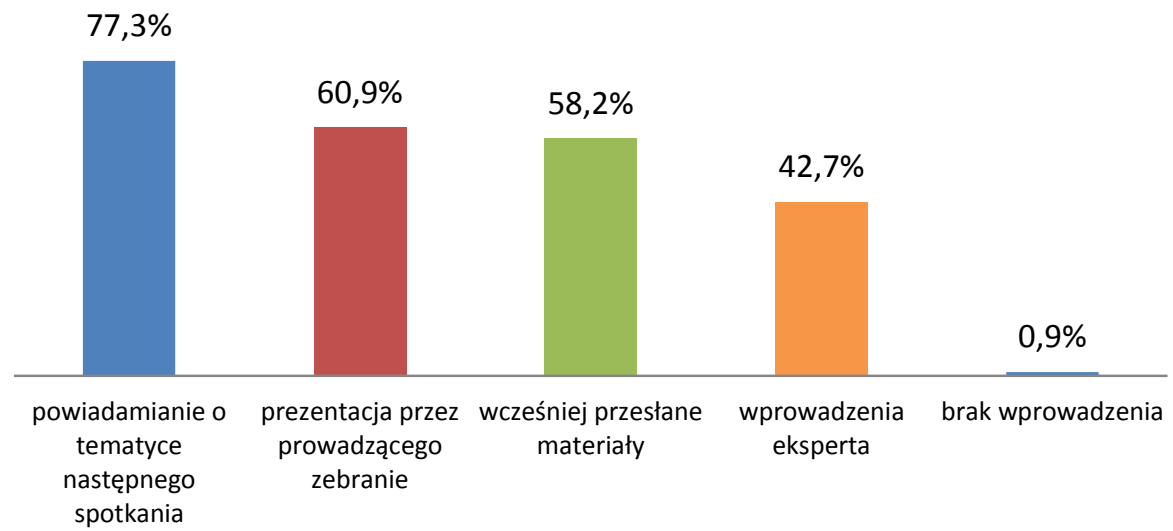

Wyk. 9. Sposoby wprowadzania członków rady do jej prac. Odpowiedzi nie sumują się do $100 \%$, gdyż respondenci mogli zaznaczyć więcej niż jedną odpowiedź. 
Należy zauważyć, że respondenci mieli możliwość zaznaczenia nieograniczonej liczby odpowiedzi, właściwych dla pracy swojej rady. Wydaje się, że w niezadowalający sposób korzysta się z wszystkich form przygotowujących do podjęcia różnorodnej problematyki. Jest to szczególnie ważne w skomplikowanym i złożonym świecie, gdzie konkretne problemy wyjaśniają i porządkują specjaliści z różnych dziedzin.

Ankieta uwzględniała także kwestię formacji członków DRD dotyczącej ich roli w podejmowaniu odpowiedzialności za diecezje. Potwierdziło takie działanie $41,9 \%$ badanych. Odpowiedzi „nie” oraz „trudno powiedzieć” skumulowały podobny odsetek respondentów, odpowiednio $29,5 \%$ i $28,7 \%$.

\section{Czy spotkania rady obejmują element formacyjny dotyczący roli jej członków w podejmowaniu odpowiedzialności za Kościół lokalny?}

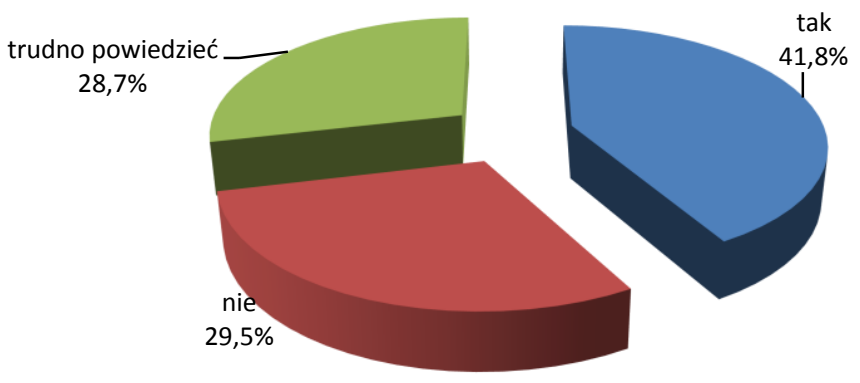

Wyk. 10. Opinia członków rady dotycząca teologicznej formacji w ramach DRD.

Uzyskane dane mogą świadczyć o tym, że w wielu wypadkach brakuje konkretnej, wielowymiarowej formacji. Intryguje także duży odsetek osób, które poprzez odpowiedź „trudno powiedzieć” nie potrafiły jednoznacznie określić, na czym polega element formacyjny w działalności ich rady. Świadczyć to może o braku wystarczającej wiedzy teologicznej, która pozwoliłaby takie rozróżnienie poczynić.

Zastanawiające jest także, że prawie połowa respondentów nie potrafiła odpowiedzieć na pytanie, czy inni członkowie ich rady są członkami parafialnych rad duszpasterskich (odpowiedź „nie wiem” zaznaczyło 49,2\% badanych). Nieco niższy odsetek osób potwierdził, że członkowie rady są w radach lokalnych $(43,9 \%)$. 


\section{Czy członkowie Waszej Diecezjalnej Rady Duszpasterskiej są także członkami Parafialnych Rad Duszpasterskich?}

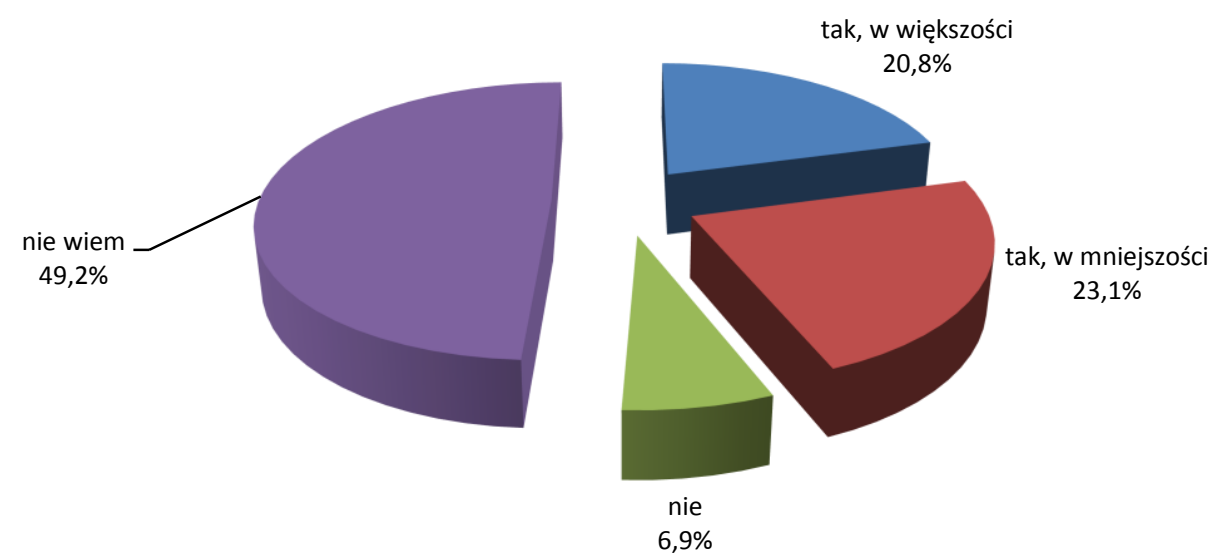

Wyk. 11. Wiedza członków na temat uczestnictwa członków DRD w pracach PRD.

Analizując uzyskane dane, można odnieść wrażenie, że członkowie rady nie mają możliwości dzielenia się własnymi, specyficznymi doświadczeniami służby w Kościele. W wielu przypadkach, rada nie jest więc miejscem wzajemnego ubogacania się i tworzenia communio, a jedynie formalnym wypełnieniem zaleceń Magisterium.

Zostało także zadane dodatkowe pytanie, dzięki któremu autorzy chcieli poznać, na ile jest realizowana ponaddiecezjalna współpraca DRD. Okazało się, że ich członkowie w większości nie zauważyli jakichkolwiek form współpracy z innymi diecezjami $(91,5 \%)$. 


\section{Czy są znane jakieś formy współpracy Waszej rady z radami innych diecezji?}

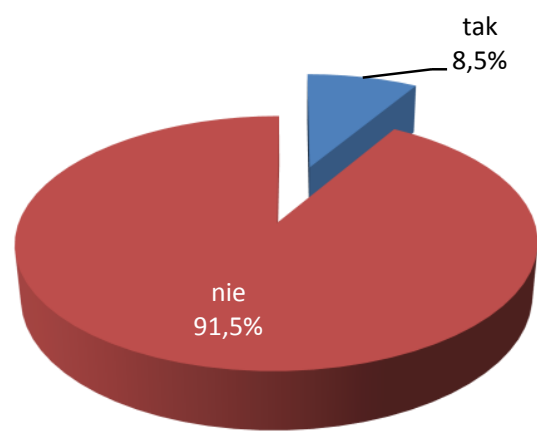

Wyk. 12. Wiedza dotycząca współpracy własnej DRD z innymi DRD.

Wyniki badań ilościowych potwierdzają też badania jakościowe, bo oto $\mathrm{w}$ kontekście planowanego I Kongresu DRD, świecki uczestnik z diecezji w zachodniej Polsce pisał: Niech inspiruje do kontaktów rad wszystkich diecezji. Wydaje się, że kongres odbyty w Licheniu we wrześniu 2012 roku, nie jest ostatnią inicjatywą, która będzie służyła takiej współpracy.

\section{Czym powinna się zająć rada?}

Respondenci pytani w badaniu, jakie są najważniejsze sprawy, którymi powinna zająć się rada, najczęściej opisywali dwa zagadnienia: ewangelizacja i młodzież. Należy zauważyć, że rzadko pojawiały się określenia: reewangelizacja czy nowa ewangelizacja. W podobnym kontekście była podejmowana problematyka młodzieży. Respondenci wyrazili także troskę o jej wychowanie. Sporo respondentów wskazywało także na potrzebę katechizacji, podkreślając konieczność katechezy dorostych. Kilku respondentów wskazało także na kwestię rodziny, uszczegóławiając ją do problemu trwatości matżeństwa, przygotowania do niego oraz życia w związach niesakramentalnych.

Respondenci wskazywali także na konieczność podjęcia przez DRD bieżących spraw oraz problemów społecznych. Osobnym, często pojawiającym się zagadnieniem, które podejmowali respondenci były szeroko rozumiane problemy Kościoła oraz stające przed nim wyzwania. Wśród ogólnych zagadnień respondenci wymieniali: sakramenty, formację, duszpasterstwo, wspólnoty. Szczegółowo zwracano uwagę na: powołania, finanse, rady parafialne i aktywność parafii. Kilka osób dostrzegło także kwestię programów duszpasterskich i rad parafialnych. 
Takie sformułowanie problemów, jakimi powinna zająć się rada, dobrze świadczy o potencjale członków DRD i ich uwrażliwieniu na znaki czasu. Bardzo trafne i dojrzałe wydają się szczegółowe zagadnienia, na które wskazywali respondenci, a które w protokołach często nie były uwzględniane. Warto w tym miejscu przytoczyć wypowiedź osoby świeckiej z południowej diecezji, która tak ocenia prace DRD: Czasami wydaje się, że członkowie rady krępuja się mówić przy biskupach o rzeczach trudnych, tematy spotkań dotycza spraw ogólnych, m.in. inicjatyw z okazji roku duszpasterskiego (hasła), zaangażowanie w ruchy i stowarzyszenia.

\section{W jaki sposób powinna wyglądać praca DRD?}

Respondenci, pytani o najlepszy sposób wprowadzenia w problematykę obrad DRD, najczęściej sugerowali wcześniej przesyłane materiały $(69,4 \%)$ oraz powiadamianie o tematyce następnego spotkania i wprowadzenia eksperta (po 26,9\%). Dodatkowo zasugerowali także inne rozwiązania, jak: wcześniejsze, wspólne ustalenie tematyki kolejnego spotkania, formę wykładów połączonych z dyskusją oraz pracę w małych grupach, które przygotują materiał na spotkanie.

\section{Jaki jest najlepszy sposób wprowadzania w problematykę rady?}

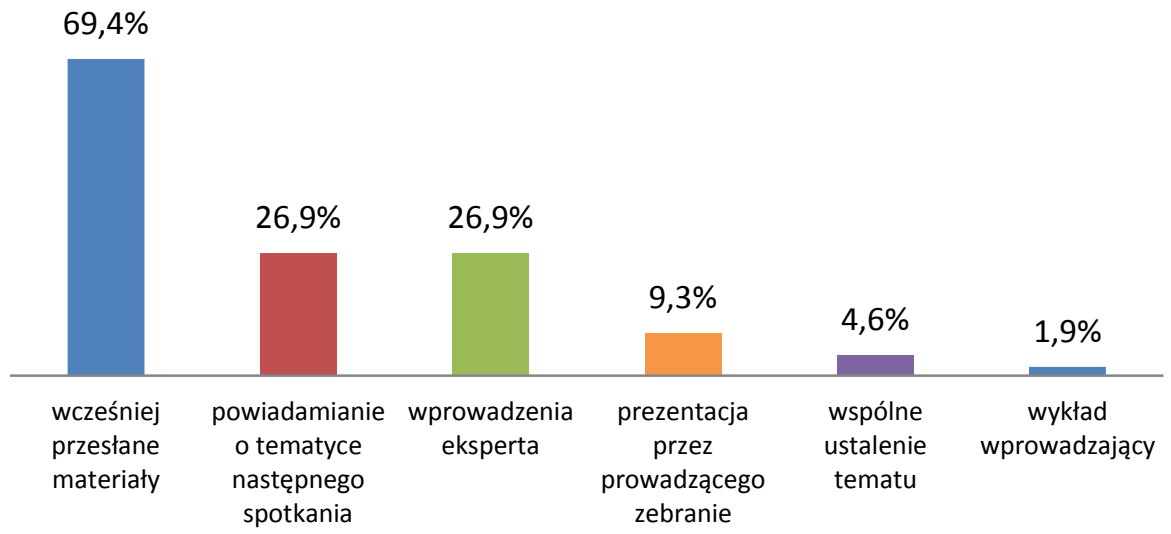

Wyk. 13. Opinia członków rady dotycząca sposobów wprowadzania w prace DRD. Odpowiedzi nie sumują się do $100 \%$, gdyż respondenci mogli zaznaczyć więcej niż jedną odpowiedź.

Zapytano także członków DRD, jak często powinna spotykać się rada. Nikt nie udzielił odpowiedzi, by spotkania odbywały się rzadziej. Pozostałe dwie odpowiedzi rozkładają głosy respondentów w podobnych proporcjach. Spośród osób, twierdzących, że rada powinna spotykać się częściej $(48,1 \%)$, najwięcej chciałoby spotkań rady raz na kwartał $(58,3 \%)$ i dwa razy w roku $(15,0 \%)$. 


\section{Czy rada powinna się spotykać:}
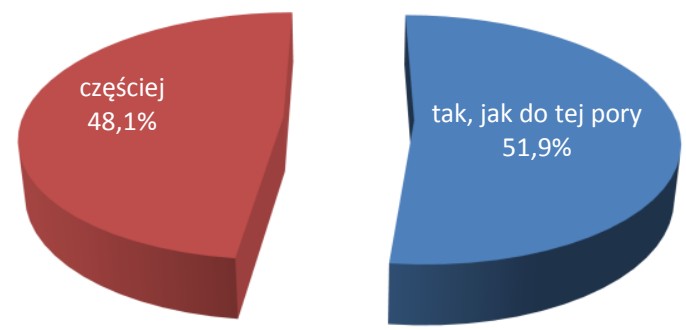

Wyk. 14. Opinia członków rady dotycząca częstotliwości spotkań DRD.

Obydwie kwestie ukazują członków DRD jako otwartych, zaangażowanych i chętnych do dalszej, konstruktywnej pracy. Należy zauważyć olbrzymi potencjał tkwiący w osobach tworzących omawiany organ doradczy w diecezjach, który nie powinien być zmarnowany.

Autorzy postanowili także sprawdzić, czy istnieje zależność między danymi zdobytymi poprzez kwestionariusz a stopniem zgodności dokumentów diecezji z Magisterium Kościoła. Zasadniczo nie ujawniły się istotne tendencje, chociaż interesującym może się wydać fakt, że lepiej oceniają pracę DRD badani z diecezji, które zostały określone najniższym stopniem zgodności. Świadczyć to może o tym, że dokumenty nie zawsze oddają w pełni działalność DRD.

\section{Korelacja $z$ diecezją}

Skorelowanie pytań związanych z podejmowanymi przez DRD problemami $\mathrm{z}$ konkretnymi diecezjami pokazało, że istnieje kilka diecezji, w których jest bardzo duża zgodność odpowiadających osób na temat pozytywnej oceny działalności DRD. Biorąc pod uwagę nazwy tych diecezji i zestawiając je z osobowościami posługujących w nich biskupów, można wnioskować, że to osobowość pasterzy nadaje pewne kierunki pracy rad.

Świecki z diecezji w zachodniej Polsce zauważył: Księża biskupi powiedzieli, co uważali za stosowne w formie podajacej. Dyskusja była pozorna. Wyczuwato się brak stuchania członków. Nawet układ stołów - akademicki: na podium: biskupi, na sali: członkowie. Wyraźnie widać, że spotkania sa czysto formalne, być może tylko dla celów statystycznych, by w sprawozdaniu podać, że DRD istnieje $i$ że się spotyka regularnie 1 do 2 razy w roku. 
Okazuje się także, że im członkowie rady bardziej są zaangażowani w tworzenie programu duszpasterskiego, tym bardziej jego końcowa wersja jest kompleksowa, rozbudowana, pragmatyczna i może stanowić dobry punkt wyjścia do konstruowania programu na poziomie parafii. Widoczna jest tutaj pewna prawidłowość, gdyż osoby, które wysoko oceniły udział rady w tworzeniu programu, równie wysoko oceniały uwzględnienie w działalności duszpasterskiej owoców pracy rady. Potwierdzeniem tej tendencji jest zestawienie częstotliwości spotkań DRD z postulatami o ich ewentualne zwiększenie. Okazuje się, że tam gdzie praca jest efektywna, członkowie DRD nie widzą potrzeby zwiększania ich częstotliwości i chcą, by rada spotykała się tak samo często, jak dotychczas.

Analizując szczegółowe zadania podejmowane przez DRD, nie widać, by zaangażowanie $\mathrm{w}$ któreś $\mathrm{z}$ nich było zdecydowanie pozytywnie ocenione $\mathrm{w}$ poszczególnych diecezjach. W tej perspektywie warto także dodać, że istnieją trzy diecezje, których członkowie DRD konsekwentnie i pozytywnie oceniają zaangażowanie w powyższe dziedziny. Pozostałe nie mają tak jednoznacznego zdania co do efektywności pracy w DRD, ale poprzez ich wypowiedzi w przesłanym kwestionariuszu, można sformułować kierunki działań, które pomogą uzyskać zamierzone cele. Wydaje się, że poruszoną kwestię należy rozpatrzyć razem z jeszcze jednym spostrzeżeniem autorów, nie związanym ściśle z przeprowadzonymi badaniami. Zauważyli bowiem wśród osób zaangażowanych w życie Kościoła brak powszechnej świadomości istnienia i działania DRD. Nikt z rozmówców autorów nie utożsamiał DRD z odrębną strukturą diecezjalną, a zawsze była ona mylona z Parafialną Radą Duszpasterską.

Zebrany materiał badawczy i wyprowadzone z niego wnioski pozwoliły na skonstruowanie szeregu postulatów.

\section{Postulaty duszpasterskie}

Myślę, stwierdził jeden świecki ze środkowej Polski, że to nie zmieni utartych sposobów dziatania. Czy rzeczywiście?

Po przedstawieniu szeregu wniosków należy ukazać postulaty, które płyną z podjętej refleksji. Trzeba pamiętać, że mają one charakter ogólny, a ich uszczegółowienie powinno odbywać się na poziomie każdej diecezji. Mają one bowiem posłużyć usprawnianiu pracy istniejących rad, a tam, gdzie ich nie ma, przemyślanemu zorganizowaniu.

\section{- Powołać rady}

Istnieją diecezje, w których nie ma w ogóle DRD. Biskupów ordynariuszy należy zachęcać do tworzenia tego ciała doradczego, które nie jest tylko wymogiem Magisterium, ale także realizacją istoty Kościoła jako communio. Po lekturze wypowiedzi członków DRD zauważyć należy, że to, co na początku trudne 
lub nawet zbędne, okazuje się dużym ułatwieniem i przynosi owoce duszpasterskie. Przy okazji warto zwrócić uwagę na konieczność zachowania właściwych proporcji w doborze członków, na co wskazuje Kodeks Prawa Kanonicznego (kan. $512 \S 1$ ).

\section{- Formować czlonków}

Priorytetowe znaczenie odgrywa formacja duchowa i teologiczna wszystkich członków rady. Szczególną uwagę należy zwrócić, odwołując się do nauczania Magisterium, na budzenie świadomości odpowiedzialności za Kościół, zarówno w wymiarze lokalnym jak i powszechnym oraz roli i zadań rady w kontekście tworzenia communio.

Przeprowadzone wcześniej analizy doprowadziły do wniosku, że im rada ma wyższy stopień zgodności z wytycznymi Magisterium, tym większa liczba ich członków nie chce zwiększać częstotliwości spotkań. Wynika z tego, że owocność pracy rady nie zależy tyle od ilości spotkań, co od ich wymiaru jakościowego. Współdecydują o nim prezentowane wcześniej postulaty, które także należy rozpatrywać $w$ perspektywie poszukiwania woli Bożej, na którą wskazuje w ankiecie kapłan z zachodniej diecezji Polski.

\section{- Przejrzeć statuty}

Ważnym problemem jest także sprawa tego, w jaki sposób konstruowane są statuty DRD. Potrzeba większej jasności celów i zadań, które nadadzą właściwy kierunek pracom rady. Ma to duże znaczenie, gdyż, jak uważa jeden pytanych duchowny z diecezji południowej Polski, chodzi o strategię działania rady. Może $\mathrm{w}$ tej perspektywie warto w poszczególnych diecezjach przejrzeć statuty DRD pod tym kątem. Warto też pomyśleć o skonstruowaniu wzorcowego statutu, który kompleksowo uwzględniałby nauczanie Magisterium przedstawione w kontekście wskazań nauk prakseologicznych.

\section{- Korzystać z nauk prakseologicznych}

W pracach DRD oprócz środków nadprzyrodzonych trzeba stosować wskazania nauk prakseologicznych. Mówią one między innymi o tym, jak skutecznie organizować pracę zespołu, motywować do konstruktywnego działania, stwarzać warunki do autentycznej komunikacji, korzystać z profesjonalnej wiedzy ekspertów, tworzyć obraz rzeczywistości na podstawie badań społeczno-religijnych i co szczególnie ważne - konsekwentnie wcielać w życie uchwalone postanowienia. Sami członkowie rad, jak świecki ze śląskiej diecezji, zauważają: Potrzeba usprawnienia przeplywu informacji od rady przez dziekanów do proboszczów $i$ egzekwowania przekazanych informacji. Dzięki temu działania DRD nie będą miały charakteru fasadowego, o którym piszą niektórzy respondenci, jak na przykład świecki z diecezji w Małopolsce: Może warto zapytać o to, czy rada jest bytem realnym, czy też fasadowym, który nijak ma się do rzeczywistości. 


\section{- Dobrze organizować prace}

Ważną rzeczą jest sposób organizacji prac DRD. Warto przyjrzeć się rozwiązaniom, jakie w tym kontekście podejmują niektóre diecezje. W diecezjach: łódzkiej, opolskiej i płockiej zebrania są zorganizowane wokół tematu wiodącego. Inny sposób prowadzenia spotkań koncentruje członków DRD wokół tematów bieżących. Duchowny z diecezji południowej podpowiada: Można by pomyśleć, aby stale dziatało Prezydium Rady i na bieżaco monitorowało pojawiające się problemy. Inny duchowny jednej ze śląskich diecezji sugeruje, by poszczególne komisje, np. do spraw ekonomicznych, do spraw kulturalnych, do spraw rodziny, spotykaty się co dwa miesiace, $w$ razie potrzeby częściej. Jakkolwiek, ważnym jest, by atmosfera tych spotkań sprzyjała otwartej dyskusji a ich uczestnicy czuli się swobodnie przy wyrażaniu swoich myśli.

\section{- Wykorzystywać potencjal intelektualny czlonków rady}

Trzeba również mądrze wykorzystywać potencjał intelektualny członków rady, co ma miejsce w niektórych diecezjach, chociażby w archidiecezji warszawskiej, gdzie szczególnie uwzględniania się zdanie jej świeckich członków. Przykładowo, na fali obecnej dyskusji na temat reformy finansowania Kościoła w Polsce, koniecznym wydaje się poruszenie tej kwestii również w ramach spotkań DRD. Należy bowiem ten problem rozważyć w szerszym kontekście finansowania działalności duszpasterskiej w diecezji. Skoro rada ma charakter doradczy, jest to odpowiednia przestrzeń, by biskup diecezjalny zapoznał się z opinią świeckich na ten temat. Nie można bowiem bagatelizować ich prawa do kreatywności i krytycyzmu. Warunkiem podstawowym jest jednak dojrzała osobowość biskupa, otwartego na konstruktywną dyskusję osób zatroskanych o dobro Kościoła (por. AS 47).

Nie można rozpatrywać problematyki działań DRD w oderwaniu od całościowego, organicznego procesu odnowy Kościoła w duchu komunijnym, co wiąże się z perspektywą ewangelizacji i nowej ewangelizacji. Warto przywołać w tym miejscu fragment Instrumentum laboris, przygotowanego na XIII Synod Biskupów, pt. Nowa ewangelizacja dla przekazu wiary chrześcijańskiej: Wymóg przekazu wiary, który nie jest przedsięwzięciem indywidualistycznym czy czynionym w pojedynkę, lecz wydarzeniem wspólnotowym, kościelnym (...) musi dotyczyć podmiotu, któremu powierzono tę duchowa czynność (...). Czy bezowocność dzisiejszej ewangelizacji (...) w czasach wspótczesnych nie jest przede wszystkim problemem natury kościelnej i duchowej? Warto się zastanowić, na ile Kościót potrafi sie jawić jako rzeczywista wspólnota, żyjąca w prawdziwym braterstwie, 
jako ciato $^{18}$. Nie chodzi więc tylko o to, aby będąc wiernym Magisterium Kościoła, powoływać DRD jako sztukę dla sztuki, ale w ten sposób urzeczywistniać istotę Kościoła rozumianego jako communio. Taka ewangelizacyjna działalność DRD, jako jednej z form współpracy i dialogu między duchownymi i świeckimi, nie tylko stanie się elementem świadectwa, ale pozwoli na to, jak to określił jeden z członków rady z diecezji świdnickiej, na wykorzystanie wyksztatconych świeckich do ewangelizacji w obszarach niedostępnych kapłanom.

Prowadzone badania działalności DRD w Polsce ukazały istniejący stan rzeczy, przyczyniając się do postawienia diagnozy. Posłużyły one jako punkt wyjścia do zgłoszenia pewnych postulatów, których realizacja może w jakimś stopniu pomóc w lepszym urzeczywistnianiu się istoty Kościoła jako communio. Trzeba mieć nadzieję że, jak to wyraził jeden świecki respondent, może właściwa ocena pracy DRD znajdzie przetożenie na poprawe tej pracy oraz tworzenie $i$ prace rad parafialnych. Działalności rad duszpasterskich na poziomie parafii będzie przedmiotem kolejnych badań, które chce podjąć Sekcja Teologii Pastoralnej Wydziału Teologicznego UKSW w perspektywie planowanego na wrzesień 2013 roku pierwszego kongresu tych rad. Należy jednak pamiętać, że podejmowane przez teologów pastoralistów inicjatywy badawcze mają sens wtedy, gdy stanowią element uwzględniany w szerszej refleksji na działalnością zbawczą Kościoła i jej usprawnianiem w kontekście współczesnych wyzwań.

\footnotetext{
${ }^{18}$ Synod Biskupów. XIII zwyczajne zgromadzenie ogólne. Nowa ewangelizacja dla przekazu wiary chrześcijańskiej. Instrumentum laboris. Watykan $2012 \mathrm{nr} 39$.
} 